\title{
Isolation and Identification of Pathogen Bacteria Associated with Farm Animals
}

\author{
Abdulkadir Musliu*, Sulaimon Adebisi, Samira Arzika, Fasiku Oluwafemi \\ Department of Science Technology, Waziri Umaru Federal Polytechnic, Birnin Kebbi, Nigeria \\ Email address: \\ musille2003@yahoo.com (A. Musliu) \\ ${ }^{*}$ Corresponding author \\ To cite this article: \\ Abdulkadir Musliu, Sulaimon Adebisi, Samira Arzika, Fasiku Oluwafemi. Isolation and Identification of Pathogen Bacteria Associated with \\ Farm Animals. International Journal of Biomedical Science and Engineering. Vol. 9, No. 3, 2021, pp. 59-66. \\ doi: $10.11648 /$ j.ijbse. 20210903.12
}

Received: June 21, 2021; Accepted: August 3, 2021; Published: August 27, 2021

\begin{abstract}
Farm animals' meat contributes significantly to the daily protein intake of many individuals but can also be a source of foodborne illnesses especially under the conditions in which animals are handled, slaughtered, transported and sold. The emergence and re-emergence of diseases due to pathogenic bacteria are the key issue of the new pattern of food trades. A total of twenty-one samples (VIS, FSA, STS, MSA, URS, UDS, and PES) were collected from farm animals from Rugga settlement of Birnin Kebbi. Some of the samples were collected using sterile swab stick while urine and stool samples were collected in sterile containers and were taken immediately to Microbiology Laboratory Waziri Umaru federal Polytechnic. The samples were bacteriologically analyzed and the isolates were identified using biochemical tests such as (indole, coagulase, catalase, urease, gluctose, lactose, maltose, motility, Voges Proskauer and methyl red). Fourteen bacterial species were isolated and identified as pathogens from the sheep samples. They are Gram positive bacteria such as Streptococcus agalactiae and Staphylococcus aureus as well as Gram negative bacteria such as Escherichia coli and Shigella sp and Salmonella sp. The isolates were identified based on their reaction to biochemical tests. The findings revealed that sheep are potential vehicles for transmitting pathogenic bacteria and the presence of these microorganisms may lead to poisoning and can as well claim the live of the sheep from which they were isolated.
\end{abstract}

Keywords: Farm Animal, Foodborne Illness, Pathogenic Bacteria, Sheep

\section{Introduction}

Farm animal play an important role in the nutrition and income of people around the world. They serve as source of meat, milk, skin and wool [36]. Farm Animal contributes significantly to the economy of farmers in the Mediterranean as well as African and Southeast Asian countries [18]. The mass production of small ruminant in the country is constrained by disease, inadequate nutrition, poor genetic resources of the local stock, marketing, social factors, structural constraints and a shortage of high level trained manpower [71]. Mohamed and Abdelsalam, [49] reported that respiratory tract infections were of common occurrence in various species of domestic and farm animals. Pathogenesis is multifactorial, and the diseases appear due to the interaction of infectious micro-organisms (bacteria, mycoplasma, viruses and fungi), host defense, environmental factors and stress [37-39].
Bacterial infection of the respiratory tract may be primary, occurring in healthy individuals or secondary to a large number of conditions which causes immunosuppression [71]. Secondary bacterial infection occurs especially when the resistance of the respiratory mucosa is lowered and bacteria growing in the upper respiratory tract extend downwards [71]. Pneumonia is a major respiratory disease of domestic animals worldwide, especially in countries where livestock management and husbandry are yet to be developed [1, 5]. The disease incidence is usually very high in these areas and this causes serious financial losses to the livestock industry [59]. Among the important infections that are frequently diagnosed in veterinary clinics and abattoirs is pneumonia [7, 24]. Sayed and Zaitoun, [63] pointed out that pneumonia is the most frequently occurring respiratory infections in domestic animals, their aetiologic agents being bacteria, viruses, parasites or concert effect of all of them, often predisposed to by several 
factors. Pneumonias can be acute, chronic or progressive [6]. In summary, in Nigeria, some livestock owners dispose of sick, debilitated and infertile animals in an effort to minimize losses, thereby leading to an increase in the risk of slaughtering and consumption of sick animals $[4,52]$. There has been little work done on this topic with regards to extensive aerobic bacteria isolation and histopathological examination in Nsukka agroecological zone of Nigeria [17].

Mastitis is one of the major pathogenic microorganism associated with farm animal, it is an inflammation of the udder resulting in a blockage of the milk duct, therefore bringing about physical, chemical and bacteriological changes in milk and pathological changes in the udder $[9,58$, 65]. Mastitis is an infection of the tissue of the breast that occurs most frequently during the time of breastfeeding [69]. It is one of the most important and influential single health disorder affecting milk production in dairy farms. It is the disease that affects the dairy industry globally and causes significant economic losses. In the United State of America, the resulting loss due to mastitis in dairy industry is about of $\$ 2$ billion annually [9]. The severe economic losses are due to reduced milk yield; milk quality and early culling of severely affected animals [70]. Also, colossal amounts are expended in antibiotic treatment of mastitis and veterinary services are wasted and economic losses are incurred due to mortality of young animals $[8,9]$.

Mastitis can be classified as either contagious or environmental mastitis [9, 66, 67]. The former is caused by organisms such as Staphylococcus aureus and Streptococcus agalactiae that are adapted to survive within the host, particularly in the mammary gland [11, 46, 47]. Environmental mastitis is caused by organisms such as E coli, Streptococcus uberis that do not usually live within the host but enter the teat canal when the cow comes into contact with a contaminated environment. [9, 40] They are common causes of clinical mastitis, with the infection occurring either between milking's such as teat contact with pathogenic material or during the udder preparation before milking [13, 15]. Elsheikh and Hassan [24] stated that Contamination with the teat end of a susceptible quarter with a pathogen is the first stage in the infection processes.

Streptococci were the first bacterial organisms to be incriminated as the cause of contagious mastitis right before the era of antibiotics. Streptococcus agalactiae (Lancefield group B), Streptococcus dysgalactiae (Lancefield group C) and Streptococcus uberis are the main streptococci species involved in mastitis $[8,10,14]$. Streptococcus agalactiae is the major cause of chronic mastitis, and is most prevalent in herds $[20,25,29,43]$. It can survive for long period only within the mammary gland and the effect of infection on udder is devastating. It could result in fibrosis and agalactiae [3, 48].

Environmental Streptococci, Streptococcus dysgalactiae and Streptococcus uberis cause both subclinical and clinical mastitis $[16,26]$. There are forty (40) different species of Staphylococcus, which are divided into coagulase positive and coagulase negative staphylococci (CNS) based on the ability to coagulate plasma [30-34]. Among these,
Staphylococcus aureusisby far the most pathogenic. It causes chronic and deep infections of the mammary gland that are extremely difficult to cure [50]. Elsewhere, It was reported to be the most frequent and predominant cause of both clinical and subclinical mastitis [41, 51].

Coagulase negative staphylococci (CNS) were traditionally considered minor pathogens ornon- pathogenic as infections with these organisms mostly remaining subclinical. However, they may cause persistent infection that can damage the udder. Some authors have reported a high percentage of clinical cases of mastitis evoked by CNS [11, 46, 47]. Escherichia coli produce endotoxin, which is responsible for many of the observed inflammatory mammary and systemic changes. Cases of coliform mastitis are usually pre-acute, acute or chronic in nature and may cause death $[35,65]$. Chronic clinical mastitis is characterized by periodic subacute to acute flare-ups that may persist for months [12]. Certain factors influence the prevalence of mastitis; such as age, parity numbers and stage of lactations where most of the new infections occur during the early parts of the dry period (little milk production) and in the first 2 months of lactation [28, 55-57].

In most countries, surveys of dairy herds indicate that there is relatively high incidence of clinical mastitis and, many farms have high prevalence of subclinical mastitis too [53]. Prevalence with infection of mastitis pathogens is about $50 \%$ in cows and quarter infection rate of about 25\% [60]. In Nigeria, Rylatt, Wyatt, and Bundesen, [61] reported a prevalence rate of $30 \%$ and $3.2 \%$ for Staphylococcus aureus from settled and traditionally nomadic herds, receptively, in Birnin Kebbi. In another study by Bala, Garba, and Yazah, [4] an incidence rate of $55.4 \%$ for Streptococcus uberis, $24.6 \%$ Streptococcus agalactiae and $12.3 \%$ Streptococcus dysgalactiae was reported in Ibadan [27]. Prevalence rate of $25.7 \%$ Staphylococcus aureus, $15.4 \%$ Streptococcus agalactiae and $14.1 \%$. Escherichia coli in bovine mastitis had also been reported [42], in Tanzania.

\section{Methods}

\subsection{Study Animals}

The Animals used on this research were Ram, Sheep, Goat and Cow.

\subsection{Sample Collection}

The isolates were collected in a slant bottle (Stock culture) and are labeled accordingly before the identification.

\subsection{Sub-Culturing of the Isolate}

The pathogens isolated from the animals collected in stock (slant bottles). Each of the isolate was sub-cultured into a prepared nutrient agar plate by streak method of inoculation after which they were incubated for 24 hour at $37^{\circ} \mathrm{C}$ before that identification.

\subsection{Identification of the Isolates}

The identification process was carried out by inoculating the organism into various selective and differential media 
namely, Eosin Metlyene agar (E.M.B), Salmonella shigella (S.S) and Macconkey agar medium this was then followed microscopic examination and Biochemical test Catalase, Oxidases, indole urea e.t.c).

\subsubsection{E.M.B}

The pathogend subculture into prepared EMB agar plate Using spread method of inoculation. After which the plate was inoculated for 24 hours at $370^{\circ} \mathrm{C}$ macroscopic examination was carried out. E.coli appear green metallic sheen while E. aerogenes appears pinkish in colour.

\subsubsection{S.S}

The same procedure was carried out for S.S agar, Microscopic examination of the pathogens shows that salmonella appears colourless in colour with back dot at the center. While Shigella appear only colourless.

\subsubsection{Macconkey Agar}

After inoculating the pathogen is Macconkey agar medium, Staph sppappear pale pink in colour, E. coli red, and Enterococcus appears red in colour.

\subsection{Microscopic Examination}

Microscopic examination was carried out by gramstain techniques, to know whether the pathogens are gram + Ve orVe and to confirmed the pathogens isolated.

\subsection{Smear Making}

A drop of distilled water was place at the center of the slide, the loopfull of the bacteria isolated was pick and emulsified on the drop of the water to make a thin smear. The smear was heat fixed and allowed for a day.

\subsection{Gram Staining and Microscopy}

The Gram staining procedure modified by Rueckert and Morgan, [60] was used in this research work. Gram staining clean glass slides were obtained and using the sterile technique a smear of each of the microorganism from $18-28$ hours culture (while micro-organism were still young) was prepared, and heat-fixed. The smear was gently stained with basic dye crystal violet and left for 1-2 minutes. This was then rinsed rapidly with water, followed by treatment with gram's iodine solution and left for 1 minute which increased interaction between the bacteria cell and the dye so that the dye was more tightly bound or the cell was more strongly stained. The iodine was then poured off, blotted and the slide or smear decolourized by washing with $95 \%$ ethanol until no more stain ran from the side. The slide was then washed well with water and stained with safranin for 30 seconds, which was then washed well and dried. Preliminary characterization bygram staining was done (using safranin) on each of the isolated using the method [12] and observed under a light microscope at X 100 and this was observed under oil immersion. The gram staining technique was used to categorize the isolated into gram negative and gram positive [18, 44-45].

\subsection{Biochemical Test for Pathogenic Bacteria}

\section{Catalase Test}

A colony of $24 \mathrm{~h}$ old culture was picked using a sterile loop and then emulsified in a few drop of hydrogen peroxide on a clean slide. Presence of effervescence indicated catalase positive reaction whereas negative reaction showed no effervescence $[62,64]$.

\section{Indole test}

The sterile wire loop was used to inoculate organism in a test tube containing $5 \mathrm{ml}$ of peptone water (medium) and incubated for $48 \mathrm{~h}$ at $37^{\circ} \mathrm{C}$. After incubation, $0.5 \mathrm{ml}$ of Kovac's reagent was added into the tube and allowed to stand for 15 minutes. A rose spank colour indicated positive reaction [62].

Coagulase Test

Two to three drops of plasma were dropped onto the real bacterial suspension. Immediate coarse clumping of the mixture within 5-10 seconds indicate positive coagulase test [62].

\section{Oxidase Test}

A piece of filter paper was soaked with oxidase reagent, a colony of test organism is then smeared on filter paper deep purple color indicate that phenylene diamine in the reagent oxidize by the oxidase in the test organism $[19,62]$.

\section{Urease Test}

A well-isolated colony was picked from the surface of the medium and the inoculated as single streak on the slant surface of Christensen's urea agar. The $\mathrm{pH}$ shift was detected by the color change of phenol red from light orange to magenta which indicated a positive result. $[12,23]$.

\section{Results}

Table 1. Sources of Isolates and their Code from farm animal.

\begin{tabular}{lll}
\hline S/No & Sources of isolates from farm animal & Isolates codes \\
\hline 1. & Vagina Goat & VRG \\
2. & Female Goat Anus & FGA \\
3. & Stool Goat & STG \\
4. & Male Goat Anus & MGA \\
5. & Goat Urine & URG \\
6. & Udder Goat & UDG \\
7. & Penis Sheep & PEG \\
8. & Vagina Sheep & VIS \\
9. & Female Sheep Anus & FSA \\
10. & Stool Sheep & STS \\
11. & Male Sheep Anus & MSA \\
12. & Sheep Urine & URS \\
13. & Udder Sheep & UDS \\
14. & Penis Sheep & PES \\
15. & Vagina cow & VRG \\
16. & Female cow anus & FCA \\
17. & Stool cow & STC \\
18. & Male cow anus & MCA \\
19. & Cow urine & URC \\
20. & Udder cow & UDC \\
21. & Penis cow & PEC \\
\hline
\end{tabular}


Table 2. Colony Characteristics and Biochemical Properties of Bacteria Isolated from Farm Animals.

\begin{tabular}{|c|c|c|c|c|c|c|c|c|c|c|c|c|c|c|c|}
\hline $\begin{array}{l}\text { ISOLATE } \\
\text { CODE }\end{array}$ & MICROSCOPY & MICROSCOPY & MO & CA & IND & GL & LAC & MA & COA & $\mathbf{A T}$ & OXI & UR & MR & VR & $\begin{array}{l}\text { BACTERIA } \\
\text { ISOLATED }\end{array}$ \\
\hline VRG & $\begin{array}{l}\text { Small circular } \\
\text { colonies }\end{array}$ & Gram-ve rod & + & + & + & + & + & + & - & - & - & - & + & - & $\begin{array}{l}\text { Escherichia } \\
\text { coli }\end{array}$ \\
\hline FGA* & $\begin{array}{l}\text { Flat circular } \\
\text { milky colonies }\end{array}$ & $\begin{array}{l}\text { Gram +ve cocci in } \\
\text { Clusters }\end{array}$ & - & + & - & + & - & - & + & - & - & - & + & - & $\begin{array}{l}\text { Staphylococcus } \\
\text { aureus }\end{array}$ \\
\hline URG* & $\begin{array}{l}\text { Small circular } \\
\text { colonies }\end{array}$ & $\begin{array}{l}\text { Gram-ve Rod in } \\
\text { chain }\end{array}$ & - & + & + & - & - & - & + & - & - & - & + & - & Shigellasp \\
\hline STG* & $\begin{array}{l}\text { Small circular } \\
\text { colonies }\end{array}$ & Gram -ve & + & + & - & + & - & + & - & + & - & - & + & - & Salmonella sp \\
\hline UDG* & $\begin{array}{l}\text { Flat circular } \\
\text { milky colonies }\end{array}$ & $\begin{array}{l}\text { Gram + ve cocci in } \\
\text { chain }\end{array}$ & - & - & - & + & - & - & - & - & - & - & - & + & $\begin{array}{l}\text { Streptococcus } \\
\text { agalactiae }\end{array}$ \\
\hline PEG & $\begin{array}{l}\text { Small circular } \\
\text { colonies }\end{array}$ & Gram-ve rod & + & + & + & + & + & + & - & - & - & - & + & - & $\begin{array}{l}\text { Escherichia } \\
\text { coli }\end{array}$ \\
\hline MGA & $\begin{array}{l}\text { Small circular } \\
\text { colonies }\end{array}$ & Gram-ve rod & + & + & + & + & + & + & - & - & - & - & + & - & $\begin{array}{l}\text { Escherichia } \\
\text { coli }\end{array}$ \\
\hline VIS* & $\begin{array}{l}\text { Flat circular } \\
\text { milky colonies }\end{array}$ & $\begin{array}{l}\text { Gram + ve cocci in } \\
\text { chain }\end{array}$ & - & - & - & + & - & - & - & - & - & - & - & + & $\begin{array}{l}\text { Streptococcus } \\
\text { agalactiae }\end{array}$ \\
\hline STS* & $\begin{array}{l}\text { Small circular } \\
\text { colonies }\end{array}$ & $\begin{array}{l}\text { Gram-ve Rod in } \\
\text { chain }\end{array}$ & - & + & + & - & - & - & + & - & - & - & + & - & Shigellasp \\
\hline MSA* & $\begin{array}{l}\text { Small circular } \\
\text { colonies }\end{array}$ & $\begin{array}{l}\text { Gram-ve Rod in } \\
\text { chain }\end{array}$ & - & + & + & - & - & - & + & - & - & - & + & - & Shigellasp \\
\hline URS* & $\begin{array}{l}\text { Small circular } \\
\text { colonies }\end{array}$ & Gram -ve & + & + & - & + & - & + & - & + & - & - & + & - & Salmonella sp \\
\hline UDS & $\begin{array}{l}\text { Flat circular } \\
\text { milky colonies }\end{array}$ & $\begin{array}{l}\text { Gram +ve cocci in } \\
\text { Clusters }\end{array}$ & - & + & - & + & - & - & + & - & - & - & + & - & $\begin{array}{l}\text { Staphylococcus } \\
\text { aureus }\end{array}$ \\
\hline PES* & $\begin{array}{l}\text { Small circular } \\
\text { colonies }\end{array}$ & Gram-ve rod & + & + & + & + & + & + & - & - & - & - & + & - & $\begin{array}{l}\text { Escherichia } \\
\text { coli }\end{array}$ \\
\hline FSA & $\begin{array}{l}\text { Small circular } \\
\text { colonies }\end{array}$ & Gram-ve rod & + & + & + & + & + & + & - & - & - & - & + & - & $\begin{array}{l}\text { Escherichia } \\
\text { coli }\end{array}$ \\
\hline VRC* & $\begin{array}{l}\text { Small circular } \\
\text { colonies }\end{array}$ & Gram-ve rod & + & + & + & + & + & + & - & - & - & - & + & - & $\begin{array}{l}\text { Escherichia } \\
\text { coli }\end{array}$ \\
\hline $\mathrm{FCA}^{*}$ & $\begin{array}{l}\text { Small circular } \\
\text { colonies }\end{array}$ & Gram -ve & + & + & - & + & - & + & - & + & - & - & + & - & Salmonella sp \\
\hline MCA & $\begin{array}{l}\text { Flat circular } \\
\text { milky colonies }\end{array}$ & $\begin{array}{l}\text { Gram+ve cocci in } \\
\text { Clusters }\end{array}$ & - & + & - & + & - & - & + & - & - & - & + & - & $\begin{array}{l}\text { Staphylococcus } \\
\text { aureus }\end{array}$ \\
\hline STC* & $\begin{array}{l}\text { Flat circular } \\
\text { milky colonies }\end{array}$ & $\begin{array}{l}\text { Gram +ve cocci in } \\
\text { Clusters }\end{array}$ & - & + & - & + & - & - & + & - & - & - & + & - & $\begin{array}{l}\text { Staphylococcus } \\
\text { aureus }\end{array}$ \\
\hline URC* & $\begin{array}{l}\text { Small circular } \\
\text { colonies }\end{array}$ & $\begin{array}{l}\text { Gram-ve Rod in } \\
\text { chain }\end{array}$ & - & + & + & - & - & - & + & - & - & - & + & - & Shigellasp \\
\hline UDC & $\begin{array}{l}\text { Small circular } \\
\text { colonies }\end{array}$ & Gram-ve rod & + & + & + & + & + & + & - & - & - & - & + & - & $\begin{array}{l}\text { Escherichia } \\
\text { coli }\end{array}$ \\
\hline PEC* & $\begin{array}{l}\text { Small circular } \\
\text { colonies }\end{array}$ & $\begin{array}{l}\text { Gram-ve Rod in } \\
\text { chain }\end{array}$ & - & + & + & - & - & - & + & - & - & - & + & - & Shigellasp \\
\hline
\end{tabular}

Keys: $\mathrm{MO}=$ Motility $\mathrm{CO}=$ Coagulase $\mathrm{IND}=$ Indole $\mathrm{GL}=\mathrm{GlucoseLAC}=$ Lactose $\mathrm{MA}=$ Mannitol $\mathrm{CAT}=\mathrm{Catalase}$ OXI $=$ Oxidase test, UR $=$ UreaMR $=\mathrm{Methyl}$ red, $\mathrm{VP}=$ VogesProskauer+ or $(+\mathrm{ve})=$ Positive- or $(-\mathrm{ve})=$ Negative .

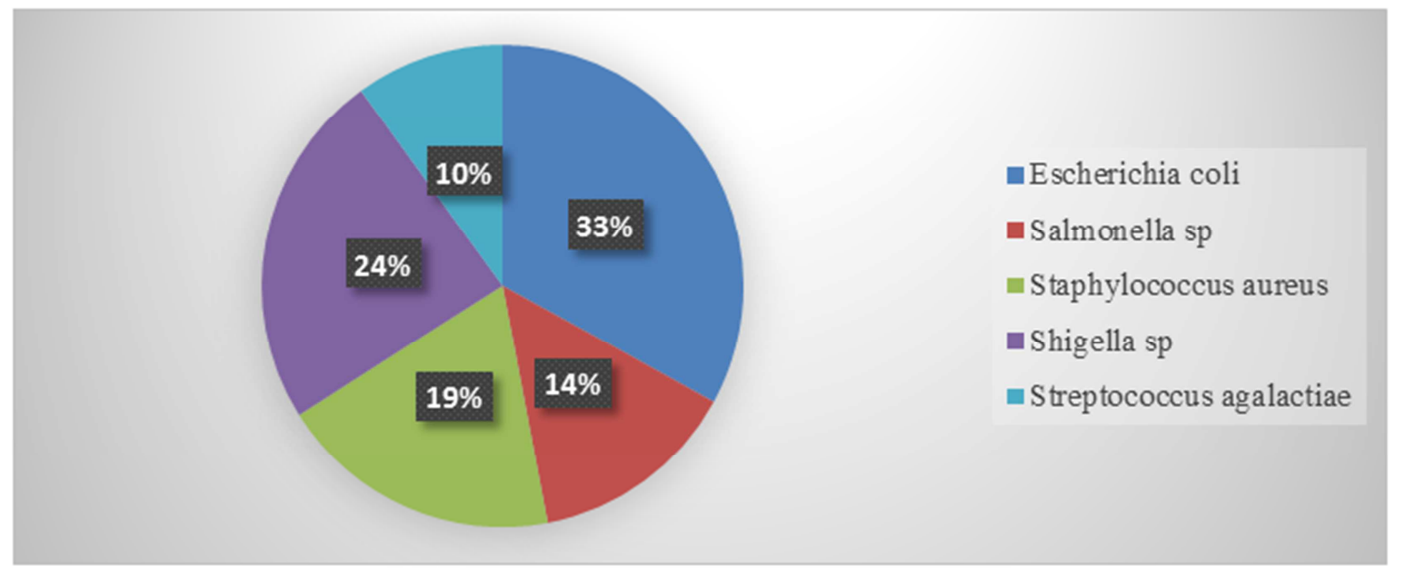

Figure 1. Percentage of occurrence of pathogens from different farm animal. 


\section{Discussion}

The sources of the sample are vagina, anus, stool, urine, udder and penis sheep. Fifteen (15) of the samples namely (Vagina swab, anus swab, and penis swab) were collected with the aid of sterile swab sticks while the urine and stool samples were collected in sterile containers then all the samples were subjected to isolation and identification of the microorganisms associated with the samples.

In Table 2, the result of the Biochemical tests performed on the samples 14 out of the 21 isolates identify as pathogen. The result revealed the presence of Gram positive bacteria such as Streptococcus agalactiae, and Staphylococcus aureus as well as Gram negative bacteria such as Escherichia coli and Shigellaspand Salmonella spin the samples which is in agreement with [45]. They were identified based on their reaction to biochemical tests. This result is in line with the findings of Capasso, [15]. In their research, they stated that microorganisms can be identified based on their reaction to biochemical test and also went further to describe the reactions of these organisms. They stated that any organism that is motile, and react to catalase, indole, and methyl red positively and react to coagulase, oxidase and urease negatively and has the ability to utilize triple sugar (Maltose, glucose, and lactose) is E. coli, any organism that is non-motile and react to catalase, indole, coagulase and methyl red positively but react negatively to oxidase and urease and could not utilize the triple sugar is Shigella dysenterea, any organism that is motile and react positively to catalase and methyl red and react negatively to coagulase and indole and could utilize triple sugar with the exception of lactose is a Salmonella $\mathrm{sp}$, any organism that is non-motile and react positively to catalase, methyl red and coagulase but react negatively to oxidase, indole and urease and could not utilize lactose and maltose is Staphylococcus aureus and any organism that reacts to catalase, indole, urease, coagulase, methyl red, and oxidase negatively and have no ability to utilize lactose and maltose is Streptococcus agalactiae. The reactions were observed during the biochemical tests.

Figure 1 shows the percentages of occurrence of pathogens in the farm animals Escherichia coli has the highest percentage of occurrence (33\%) followed by Shigellasp (24\%) while Streptococcus agalactiae has the lowest occurrence of (10\%).

Finally, the bacteria isolated from the VIS sample after identification was Streptococcus agalactia, from STS and MSA was Shigellasp, from URS was Salmonella $s p$, from UDS was Staphylococcus aureus, and from PES and FSA wereEscherichia coli. The present of these pathogenic bacteria in the farm animals implies that the animals used in this research are not healthy and if the meat is consumed by human can lead to food poisoning.

\section{Conclusion}

It can be concluded that pathogenic bacteria capable of causing food poisoning were isolated from live animals using microbial analysis. Also such bacteria can be identified using appropriate biochemical tests thereby providing information on their microbial quality. The presence of bacterial load can lower the nutrition value of these foods due to food poisoning and some intestinal diseases. Routine microbial analysis of animals most especially sheep in Rugga settlement of Birnin Kebbi be carried out to prevent outbreak of food poisoning and animal diseases. Finally, proper steps should be taken to ensure that the occurrence of such organisms in these animals is kept within limits so as to save the lives of these animals.

\section{References}

[1] Acha, N. P. and Szyfres, B. (2003). Zoonoses and Communicable Diseases Common to Man and Animals. Third edition, vol. 1. Pan American Health Organization (PAHO), Washington, DC.

[2] Alton, G. G., Jones, L. M., Angus, R. D. and Verger, J. M. (1988) Techniques for the brucellosis laboratory (1St ed). Institut National Recherche Agronomique (INRA), Paris. Pp 190.

[3] Anon (2001). Brucellosis in sheep and goats. In: Report of the European Commission Scientific Committee on Animal Health and Animal Welfare. SANCO.C.2/AH/R23/2001, pg 188.

[4] Bala, A. N, GARBA, A. E. and YAZAH, A. J. (2011). Bacterial and parasitic zoonoses encountered at slaughter in Maiduguri abattoir, North-eastern Nigeria. Veterinary World, 4 (10): 437-443.

[5] Balows, A., Truper, H. G., Dworkin, M., Harde, W. andSchleifer, K. H.(1992) The prokaryotes, 2nd ed3, pp 2673 2937 Springer-Verlag KG, Berlin, Germany.

[6] Bell, S. (2008). Respiratory diseases in sheep 1, Differential diagnosis and epidemiology. BVA In - Practice, 30 (4): 200207.

[7] Bercovich, Z. (1998). Maintenance of Brucellaabortus-free herds: A review with emphasis on the epidemiology and the problems in diagnosing brucellosis in areas of low prevalence. Veterinary Quarterly, 20: 81-88.

[8] Blasco, J. M. (1997). Advantages and inconvenience of Brucellmelitensis Rev. 1 Vaccine for the prophylaxis of brucellosis in small ruminants. WHO meeting on development of new/improved brucellosis vaccine. Geneva. December 1112.

[9] Blowey, R. W. (1999). A veterinary book for dairy farmers, $\left(3^{\text {rd }}\right.$ Ed). Farming Press Books, London.

[10] Boschiroli, M. L., Foulongne, V., and O'callaghan, D. (2001). Brucellosis: A world-wide Zoonosis. Current Opinion in Microbiology, 4: 58-64.

[11] Bramley, A. J. and Dodd, F. H. (1984). Reviews of the progress of dairy science: mastitis control progress and prospects. Journal of Dairy Research, 51: 481-512.

[12] Breen, J. E., Green, M. J. and Bradley, A. J. (2009). Quarter and cow risk factors associated with the occurrence of clinical mastitis in dairy cows in the United Kingdom. Journal of Diary Science, 92: 2551-2561. 
[13] Burgeus, F., Little, C., Allen, G, Williamson, K. and Mitchelli, R. T. (2005): "Prevalence of Campylobacter, Salmonella, and Escherichia Coli on the External Packaging of Raw Meat". Journal of Food Protection 68 (3): Pp469-475.

[14] Burnett, W. G. (1976) Oral microbiology and infectious disease. $4^{\text {th }}$ Ed. P. M Publ. The Williams and Wilkins Company. 428 East Preston street Baltimore. Md. 21202. USA. Pp540.

[15] Capasso, L. (2002). Bacteria in two-millennia-old cheese, and related epizoonoses in Roman populations. Journal of Infection, 45: 122-127.

[16] Cappuccino, J. G. and Sherman, N. (2010). Microbiology: A Laboratory Manual. $7^{\text {th }}$ edition. The Pearson Education. Darling Kindersley (Ind) Pvt.

[17] Centers for Disease Control and Prevention (2010). Brucellosis (Brucellamelitensis, abortus, suis and canis). www.cdc.gov/ncidod/diseaseinfo/brucellosis_g.htm. Accessed February 2, 2010, 9:44 am.

[18] Chakrabouty, S., Kumar, A., Tiwari, R., Rahal, A., Malik, Y., Dhama, K., Pal, A. and Prasad, M. (2014). Advances in diagnosis of respiratory diseases of small ruminants. $V$ e $t$ e ri $n$ a $r$ y $M$ e di cin e International, 2014: 1-16. doi: $10.1155 / 2014 / 508304$.

[19] Cheesbrough, M., 2006. District Laboratory Practice in Tropical Countries. 2nd Edn., Cambridge University Press, Cambridge, UK., ISBN-13: 9781139449298.

[20] China B., and Goffaux, F., (1999). Secretion of virulence factors by Escherichia coli. Veterinary Research, 30: 181202.

[21] Craven, N. and Williams, M. R. (1985). Defences of the bovine mammary - gland against infection and prospects for their enhancement. Veterinary Immunopathology. 10, 71-127.

[22] Cullor, J., (1996). Endotoxin and disease in food animals. Comparative Continous. Education. Food Animal. 18: 31 - 38.

[23] Dussault G, Perfilieva G, Pethick J. (2005) Implementing the WHO Global Code of Practice on International Recruitment of Health Personnel in the European Region. Copenhagen, WHO Regional Office for Europe.

[24] Elsheikh, H. M. and Hassan, S. O. (2012). Pneumonia in goats in Sudan. I $n$ t e $r n$ a tio $n$ al $J$ o $u r n$ al of Animal and Veterinary Advances, 4 (2): 144 - 145.

[25] Enany, M. E., Riad, E. M. and Wahdan, A. (2012). Bacterial causes of pneumonia in buffalo calves. Suez Canal Veterinary Medicine Journal, XVII (2): 27 - 38.

[26] Erskine, R. J (2001) Mastitis control in dairy herd. In herd health: food animal's production medicine. $3^{\text {rd }}$ Ed. Radostits editor. W B Saunders, Philadelphia. Pp 1-8.

[27] Falade, S. (1978). A comparison of three serological tests for the diagnosis of caprine brucellosis. Research in Veterinary Science, 24: 376-379.

[28] Farrell, I. D. (1974). The development of a new selective medium for the isolation of B. abortus from contaminated sources. Research in Veterinary Science, 16: 280-286.

[29] Freney, J., Bland, S., Etienne, J., Desmonceaux, M., Boeufgras. J. M.. and. Seurette., J. F. (1992) Description and evaluation of the Sem-automated 4 - hour rapid ID 32 Strep method for identification of streptococci and members of related General. Journal of Clinical Microbiology, 30: 26572661.

[30] Giesecke, W. H. (1998). The prevalence and economic significance of mastitis in RSA. In: Vanden Heever, L. W. and Glsecke, W. H. (Eds). 1979. Proceedings of the 1st SA Symposium On Mastitis Control in Dairy Herds. Pretoria, 10 $12^{\text {th }}$ August 1978, South African Veterinary Association, pp. 30-43.

[31] Gill, S. R., Founts, D. E., Archer, G. L., Mongodis, E. F., Deboy, R. T., Ravel, J., Paulsen, I. T., Kolonay, J. F., Brinkac, L., Beanan., M., Dodson, R. J., Daughterry, S. C., Madupu, R., Angiuoli, S. L., Durkin, A. S., Haft, D. H., Vamathevan, J., Khouri, H., Utterback, T., Lee, C., Dimitrov, G., Jiang, I., Qin, H., Weidman, J., Tran, K., Kang, K., Hance, I. R., Nelson, K. E., Fraser, C. M. (2005)."Insights on evolution of virulence and resistance from the complete genome analysis of an early methicillin-resistant Staphylococcus aureus strain and a biofilm- producing smethicillin- resistant Staphylococcus epidermidis strain”. Journal of Bacteriology, 187 (7): 24262438.

[32] Godfroid J., Bosman P. P, Herr S. and Bishop G. C. (2004a). Bovine brucellosis. In: Coetzer J. A. W and Tustin R. C (Eds), Infectious Diseases of Livestock with Special Reference to Southern Africa. Oxford University Press, Capetown, 2: 15101527.

[33] Godfroid, J. A., Cloeckaert, J. P., Liautard, S., Kohler, D., Fretin, K., Walravens, B. GarinBastuji and Letesson, J. J. (2005). From the discovery of the Malta fever's agent to the discovery of a marine mammal reservoir, brucellosis has continuously been a reemerging zoonosis. Veterinary Research, 36: 313-326.

[34] Godfroid, J. and Kasbohrev, A. (2002). Brucellosis in the European Union and Norway at the turn of the twenty-first century. Veterinary Microbiology. 90: 135-145.

[35] Golodetz, C. and White, M. (1983). Prognosis for cows with severe clinical coliform mastitis. Veterinary Records, 112: 402-403.

[36] Habashy, H. F., Fadel, N. G. and EL Shorbagy, M. M. (2009). Bacteriological and pathological studies on the causes of mortalities among sheep in Sharkia-Governorate farms. Egyptian Journal of Comparative Pathology and Clinical Pathology, 22 (1): 130-146.

[37] Herr S. (1994). Brucellamelitensis infection, In: Coetzer J. A. W, Thomson G. R and Tustin R. C (eds), Infectious Diseases of Livestock with special reference to Southern Africa. Oxford University Press, Capetown, 2: 1073-1075.

[38] Hirsh, D. C., Kirkham, C., and Wilson, W. D. (1993). Linkage of serum resistance, aerobactin production, and resistance to antimicrobial agents on conjugal plasmids in some strains of Escherichia coli isolated from septic foals. American Journal Veterinary Research, 54: 878-881.

[39] Junaidu, A. U., Salihu, M. D and Gulumbe, M. L. (2006). Seroprevalence of Brucellosis in sheep in Sokoto city abattoir. Pakistan Journal of Biological Sciences, 9 (14): 2696-2698.

[40] Kolar, J. (1995). Some experience from brucellosis control with Rev. 1 vaccine in a heavily infected country - Mongolia. FAO/WHO/OIE Round table on the use of Rev. 1 vaccine in Small Ruminants and Cattle. CNEVA, Alfort, France September 21-22. 
[41] Kuroda, M., Ohta, T., Uchiyama, I., Baba, T., Yuzawa, H., Kobayashi, I., Cui, A., Oguchi, A., Aoki, K., Nagai, Y., Lian, J., Ito, T., Kanamori, M., Matsumaru, H., Maruyama, A., Murakami, H., Hosoyama, A., Mizutaniui, Y., Takahashi, N. K., Sawano, T., Inocue, T., Kaito, C., Sekimizu, K., Hirakawa, H., Kuhara, S., Goto, S., Yabuzaki, J., Kanechisa, M., Yamashita, A., Oshima, K., Furuya, K., Yoshino, C., Shiba, T., Hattori, M., Ogasawara, N., Hayashi, H. and Hiramatsu, K. (2001) Whole genome sequencing of methicillin-resistant Staphylococcus aureus. Lancet, 357: 1225-1240.

[42] Lilenbaum, W., de Souza, G. N., Ristow, P., Moreira, M. C., Fraguas, S., Cardoso Vda, S. and Oelemann, W. M. (2007). A serological study on Brucellaabortus, caprine arthritisencephalitis virus and Leptospira in dairy goats in Rio de Janeiro. Brazilian Veterinary Journal, 173: 408-412.

[43] Linton, A. H. and Robinson, T. C (1984) Studies on the association of Escherichia coli with bovine mastitis. British Veterinary Journal, 140, 368-373.

[44] Madigan, M. and Martinko, J. (2005) (Eds) Brock Biology of Microorganism (11 ${ }^{\text {th }}$ Ed) Prentice HIl. ISBN 0131443291.

[45] Mantur, B. G., Amarnath, S. K. and Shinde, R. S. (2007). Review of clinical and laboratory features of human brucellosis. Indian Journal of Medical Microbiology, 25: 188202 .

[46] Marín, C. M., Alabart, J. L. and Blasco, J. M. (1996a). Effect of antibiotics contained in two Brucella selective media on growth of B. abortus, B. melitensis and B. ovis. Journal of Clinical Microbiology, 34: 426-428.

[47] McDermott, J. J and Arimi, S. M. (2002). Brucellosis in subsaharan Africa: epidemiology, control and impact. Veterinary Microbiology, 90: 111-134.

[48] McDonald, J. S. (1997) Streptococcal and Staphylococcal mastitis. In: Jarret, J. (Ed): The Veterinary Clinic of North America. Large Animal Practice. Symposium on Bovine mastitis. W. B. Sounders Co, USA, pp 269-285.

[49] Mohamed, R. A. and Abdelsalam, E. B. (2008). A review on pneumonic pasteurellosis (respiratory mannheimiosis) with emphasis on pathogenesis, virulence mechanisms and predisposing factors. Bulgarian Journal of Veterinary Medicine, 11 (3): 139-160.

[50] Musa, M. T., Eisa, M. Z., El Sanousi, E. M., Abdel Wahab, M. B. and Perrett, L. (2008). Brucellosis in camels (Camelusdromedarius) in Darfur, Western Sudan. Journal of Comparative Pathology, 138: 151-155.

[51] Myllys, V. and Rautala, H. (1995). Characterization of clinical mastitis in Prim parous heifers. Journal of Dairy Science. 78: $538-545$.

[52] Nicoletti, P. (1993). The Eradication of Brucellosis in Animals. Saudi Medical Journal, 14: 4, 288-292.

[53] Nuru, S. (1982). Problems and concepts of the Nigerian beef industry. In: proceedings of the National Conference on beef production held at National Animal Production Research Institute, Shika-Zaria, Nigeria.

[54] Ocholi, R. A., Kwaga, J. K., Ajogi, I., Bale, J. O. (2005). Abortion due to Brucellaabortus in sheep in Nigeria. Revue Scientific Technical Office International des Epizooties, 24: 973-979.
[55] Pappas, G. and Papadimitriou, P. (2007). Challenges in Brucellabacteraemia. International Journal Antimicrobial Agents, 30 (Suppl. 1), S29-31.

[56] Paulrud, C. O. (2005). Basic concepts of the bovine teat canal. Veterinary Research. Communum, 29: 215-245.

[57] Peery, T. M. and Belter, L. F. (1960). Brucellosis and heart disease. II. Fatal brucellosis: a review of the literature and report of new cases. American Journal of Pathology, 36: 673-697.

[58] Radostits O. M, Blood D. C and Gay C. C (1994a). Brucellosis caused by BrucellamelitensisIn: Veterinary Medicine, a text book of the diseases of cattle, sheep, pigs, goats and horses. $8^{\text {th }}$ Edition, The Barth Press, Avon, pp 787-813.

[59] Raji, M. A., Adogwa, A. T., Natala, A. J. and Oladele, S. B. (2000). The prevalence and gross pathologic lesions of ovine and caprine pneumonia caused by bacterial agent in Zaria, Nigeria. Ghana Journal of Science, 40: 3-8.

[60] Rueckert A, H. W. Morgan, Removal of contaminating DNA from polymerase chain reaction using ethidium monoazide. $J$. Microbial. Methods, 68 (2007), pp. 596-600.

[61] Rylatt, D. B., Wyatt, D. M. and Bundesen, P. G. (1985). A competitive enzyme immunoassay for the detection of bovine antibodies to Brucellamelitensis using monoclonal antibodies. Veterinary Immunology Immunopathology, 8: 261-271.

[62] Saran, A. and Leitner, G. (2000) Interactions between bacteria, immunity and therapy in mammary gland. Proceeding. IDF, International Symposium. Immunology of Ruminant Mammary Gland. Stresa, Italy, 290-29.

[63] Sayed, S. M. and Zaitoun, A. M. A. (2009). Aerobic bacterial pathogens of pneumonic feedlot buffalo-calves in Assuit Governorate, Egypt. AssuitUniversity Bull e ti n o f Environ mental Res earch, 12 (1): 55-61.

[64] Schnurrenberger, P., Sharman, R. and Wise, G., (1987). Attacking Animal Diseases. Concepts and Strategies for Control and Eradication. Iowa State University Press. Ames, Iowa.

[65] Sharma, N. (2007) Alternative approach to control intrammary infection in dairy cows- A review. Asian Journal Animal Veterinary Advance, 2 (2): 50-62.

[66] Sompolinsky, D., Samra, Z., Karakawa, W. W., Vann, W. F., Scheerson, R. and Malik, Z. (1985). Encapsular types of Staphylococcus aureus from different source and relationship to phage types. Journal of Clinical Microbiology, 22: 828-834.

[67] Sordillo, L. M. and Streicher, K. L. (2002). Mammary gland immunity and mastitis susceptibility. Journal of Mammary Gland Biology Neoplasia, 7: 135-146.

[68] Spellerberg, B. and Brandt, C. (2007). Streptococcus In: Patrick, R. M., Baron, E. Jo, Micheal, A. P., Fred, C. T. and Robert, H. Y (ed.), Manuals of clinical microbiology $9^{\text {th }}$ Ed Pp 412-429. American Society for Microbiology, Washington, D. C.

[69] Sriranganathan, N., Seleem, M. N., Olsen, S. C., Samartino, L. E., Whatmore, A. M., Bricker, B., O'Callaghan, D., Halling, S. M., Crasta, O. R., Wattam, R. A., Purkayastha, A., Sobral, B. W., Snyder, E. E., Williams, K. P., Yu G-, X., Fitch, T. A., Roop, R. M., de Figueiredo, P., Boyle, S. M., He, Y. and Tsolis, R. M., (2009). Genome mapping and genomics in animalassociated microbes. In: Brucella, Springer (Chapter 1). 
[70] World Health Organization (WHO), (2007). Protein and amino acid requirements in Human nutrition. WHO Technical Report Series.

[71] Yesuf, M., Mazengia, M. and Mersha, C. (2012).
Histopathological and Bacterial examination ofpneumonic lungs of small ruminants slaughtered at Gondar, Ethiopia. American - Eurasian Journal of Scientific Research, 7 (6): 226-231. 